\title{
An ergonomics and online marketing applications in leather products industry
}

\author{
E Nurmianto*1, B Amaliah ${ }^{2}$, A Anzip ${ }^{3}$ \\ ${ }^{1}$ Department of Industrial Engineering - Faculty of Industrial Technology, \\ ${ }^{2}$ Department of Information Engineering - Faculty of Information, \\ ${ }^{3}$ Department of Mechanical Engineering - Faculty of Vocation, \\ Institute Teknologi Sepuluh Nopember, Surabaya, Indonesia 60111 \\ *nurmieko@gmail.com
}

\begin{abstract}
Leather Handicraft Products has been fostered through IBPE (Ipteks Bagi Produk Ekspor) Program In Sidoarjo District, East Java Province to improve the management of SME (Small and Medium Enterprises) development covering management, marketing, human resources and facilities. SMEs that become partners are CMP and DJA. The products produced by both SMEs are products with high quality leather raw materials. Both SMEs wish to expand their business to foreign level but are constrained by quality, unqualified labor, and quality. From the menu then as a form of community service, researchers conduct training and mentoring which includes: Training 1: Online Marketing Training, Training 2: Occupational Health and Safety, Training 3: Practical English Training, Training 4: Website Creation Mentoring,. Finally expected after the above training, both SMEs can develop abilities to the level overseas and the results of this service can be a reference for other researchers to improve the welfare of SMEs in Indonesia. Ergonomics is applied in accordance with solution in all sectors.

Keywords : Ergonomics, Leather Craft Product, Small Medium Entreprise, Website, Occupational Health and Safety
\end{abstract}

\section{Introduction}

\subsection{Background.}

CMP and DJA are industries engaged in the field of leather craft. Marketing strategy conducted by both SMEs is in the conventional way that is by participating in craft exhibitions in several cities and distributing brochures to prospective customers, but also the two SMEs using a showroom owned to peddle their products.

The average sales asset of both SMEs is almost similar that reaches Rp 0.7 billion per year. While the products produced by DJA averages 16,000 units of products per year, while.CMP averages 6000 units of products per year. Products from both SMEs have been used in various cities and high quality is evidenced by the level of customer satisfaction that entraps Tanggulangin as a leather craft center in East Java.

In the present information is circulating very quickly and easily so many emerging national online stores such as Bukalapak and Tokopedia and online stores abroad such as Alibaba, Amazon, and Ebay, 
known as e-commerce. However, both SMEs have not used these online services due to the lack of human resources capabilities that can manage them.

Another problem for both SMEs is also due to the lack of English proficiency of employees to serve foreign orders.

From the SWOT analysis (Strength, Weakness, Opportunity, Threat) there are opportunities: both SMEs are eligible to export so if this is facilitated then both SMEs can improve their welfare. Issues / threats that are still faced in the form of: Manpower who has not been able to serve foreign demand and unavailability of marketing strategy to sell leather products to foreign countries.

\subsection{Problems}

From the description above can be concluded the problems faced by both SMEs, among others: 1 . Lack of utilization of the latest technology that is e-commerce, as evidenced by sales that are only done conventionally, 2. Lack of health and safety awareness, 3. Lack of foreign language skills especially English employees who are the standard to do marketing Overseas, and 4. Lack of existing human resource capacity to manage existing online services so as to avoid online marketing.

\subsection{Solution}

Based on the above problems so that researchers formulate some solutions, among others, 1 . Online Marketing Training using online services available to help human resources both SMEs in order to keep up with the times and keep the existence of both SMEs on the market, 2. Improving occupational safety and health by training HSE and aiding with fire extinguiser, 3. Practical English Training, which aims to Employees of both SMEs can serve foreign guests well, and 4. Assistance Website Creation for both SMEs could improve business to abroad with a very low cost compared with conventional.

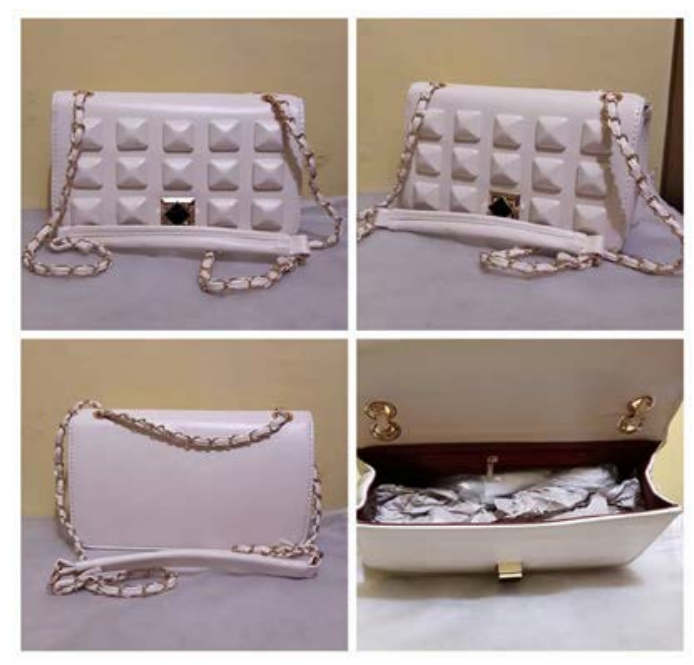

Figure 1. Example of CMP Leather Products

\section{Literature Review}

\subsection{Electronic Commerce (E-Commerce)}

Electronic Commerce or E-Commerce is a trading or trading facility conducted through the internet or social media network (1). E-commerce can also be reviewed from several perspectives follows:

1. Communication Perspective E-commerce is the delivery of product or service information and payment through electronic means.

2. Business Process Perspective

E-commerce is an application that automates transactions and company workflows 
3. Service Perspective

E-commerce is one tool that meets the wishes of companies and consumers in cutting costs in the speed of service and convenience.

4. Online Perspective

E-commerce deals with the capacity to sell products and information on the internet and other online services.

2.1.1 Classification of E-Commerce. The classification of e-commerce can be done based on the type of transaction. Based on the transaction e-commerce is divided into 4 types (1), among others:

1. Business to business (B2B)

In e-commerce business to business, the process of transaction and interaction is between one company and another company. One example of this e-commerce model is Krakatau Steel (www.krakatausteel.com) where the partner company can register its company and order steel from Krakatau Steel company.

2. Business to Consumer (B2C)

In e-commerce business to consumer, transaction and interaction process is between the company and the customer. One example of this e-commerce model is Traveloka (www.traveloka.com) which traveloka company sells its services through the internet.

3. Consumer to Consumer (C2C)

An e-commerce model in which individuals or individuals as sellers interact and transact directly with other individuals as buyers. This type of e-commerce concept is widely used in online marketplace sites (market) or auction (auction). An example of an ecommerce portal applying the C2C concept is Bukalapak (www.bukalapak.com).

4. Consumer to Business (C2B)

It is an e-commerce model in which individual or individual business actors transact or interact with one or more companies. An example of an e-commerce portal applying a business model like this is Google Playstore where users peddle their apps on the platform.

2.1.2 Benefits of E-commerce. Kong and Liu (1) also formulates the benefits that can be obtained from e-commerce for the organization:

1 Expanding sales field to the national and foreign markets.

2 Reduce paper making, processing, distribution, storage and retrieval costs.

3 Enable product reduction and overhead by simplifying supply chain and "pull" type management.

4 Reduce time between capital outlay and acceptance of products and services.

5 Supporting business process reengineering efforts.

6 Minimize the cost of internet telecommunication is cheaper than VAN.

7 Access information more quickly.

Besides having benefits for the company, according to Kong and Liu (1) E-commerce also has benefits for consumers, namely:

1 Allow customers to shop or make other transactions 24 hours a day throughout the year from almost any location using Wi-Fi facilities.

2 Provide more choices to customers.

3 Delivery becomes very fast.

4 Customers can receive relevant information in detail in seconds rather than days or weeks.

5 Give the place to other customers in the electronic community and exchange ideas and experiences.

6 Facilitating the existing competition will ultimately result in substantial discounts.

According Kong and Liu (1) in addition to benefits to the organization, e-commerce is also beneficial to the community, among others: 
1 Allow people to work at home and not have to go out to shop. This results in lower traffic flow on the road and reduces air pollution.

2 Allow some merchandise to be sold at a lower price.

3 Enable people in third-world countries and rural areas to enjoy the variety of products and services they will find hard to get without e-commerce. Of a company.

\subsection{Ergonomics, Occupational Heath and Safety}

Ergonomics $(2,3)$ Occupational safety and health $(\mathrm{OSH})$, also commonly referred to as occupational health and safety (OHS), occupational health, (4) or workplace health and safety (WHS), is a multidisciplinary field concerned with the safety, health, and welfare of people at work. These terms also refer to the goals of this field, so their use in the sense of this article was originally an abbreviation of occupational safety and health program/department etc. The goals of occupational safety and health programs include to foster a safe and healthy work environment. (5) OSH may also protect co-workers, family members, employers, customers, and many others who might be affected by the workplace environment. In Indonesia, the term occupational health and safety is referred to as occupational health and occupational and non-occupational safety and includes safety for activities outside of work(6).

\subsection{Website}

Website or website is a collection of pages that display the media information can be text, photos, or video and connected through the network pages (hyperlink). A user can access the website through a web opener or known as a web browser by entering the address of the website page. Some examples of famous web browsers include Google Chrome, Firefox, and Microsoft Edge (7).

\subsection{English}

English is one of the most important foreign languages because it has a very strategic position, that is besides as a means of communication as well as intercultural language. For example, Japanese who come to Indonesia will ask questions in English and not Japanese. In addition, English is also the first foreign language that is considered important for the purpose of accessing information, absorption and development of science, technology, and cultural arts because the information contained in this world mostly use English as the language of its publication.

\section{Targets and Output}

Target is in the form of improving the welfare of the community The output of community service is: Increasing the ability of Human Resources in CMP and DJA. After the training, both SMEs are expected to serve overseas customers, can use online marketing media, and have a website as a medium of online marketing both SMEs and that is mainly the two SMEs can be independent after the training ended.

Table 1. Predicted results of training activities

\begin{tabular}{|c|l|}
\hline Before the IBPE program & \multicolumn{1}{c|}{ After the IBPE program } \\
\hline $\begin{array}{c}\text { Human Resources is not qualified to } \\
\text { converse in English. }\end{array}$ & $\begin{array}{l}\text { Human Resources can serve visitors who speak } \\
\text { English. }\end{array}$ \\
\hline $\begin{array}{c}\text { Marketing is still done conventionally } \\
\text { (through exhibitions and brochures) that } \\
\text { cost not less }\end{array}$ & $\begin{array}{l}\text { Marketing can evolve into the online realm using } \\
\text { existing online marketing services }\end{array}$ \\
\hline The absence of media to promote SMEs & The availability of a personal website to promote SMEs \\
\hline
\end{tabular}




\begin{tabular}{|l|l|}
\hline The absence of health and safety awareness & that can be accessed anytime, anywhere, and by anyone. \\
\hline
\end{tabular}

\section{Method Of Implementation}

The method of implementing the existing training activities is illustrated in the solution problem diagram in Figure 2.

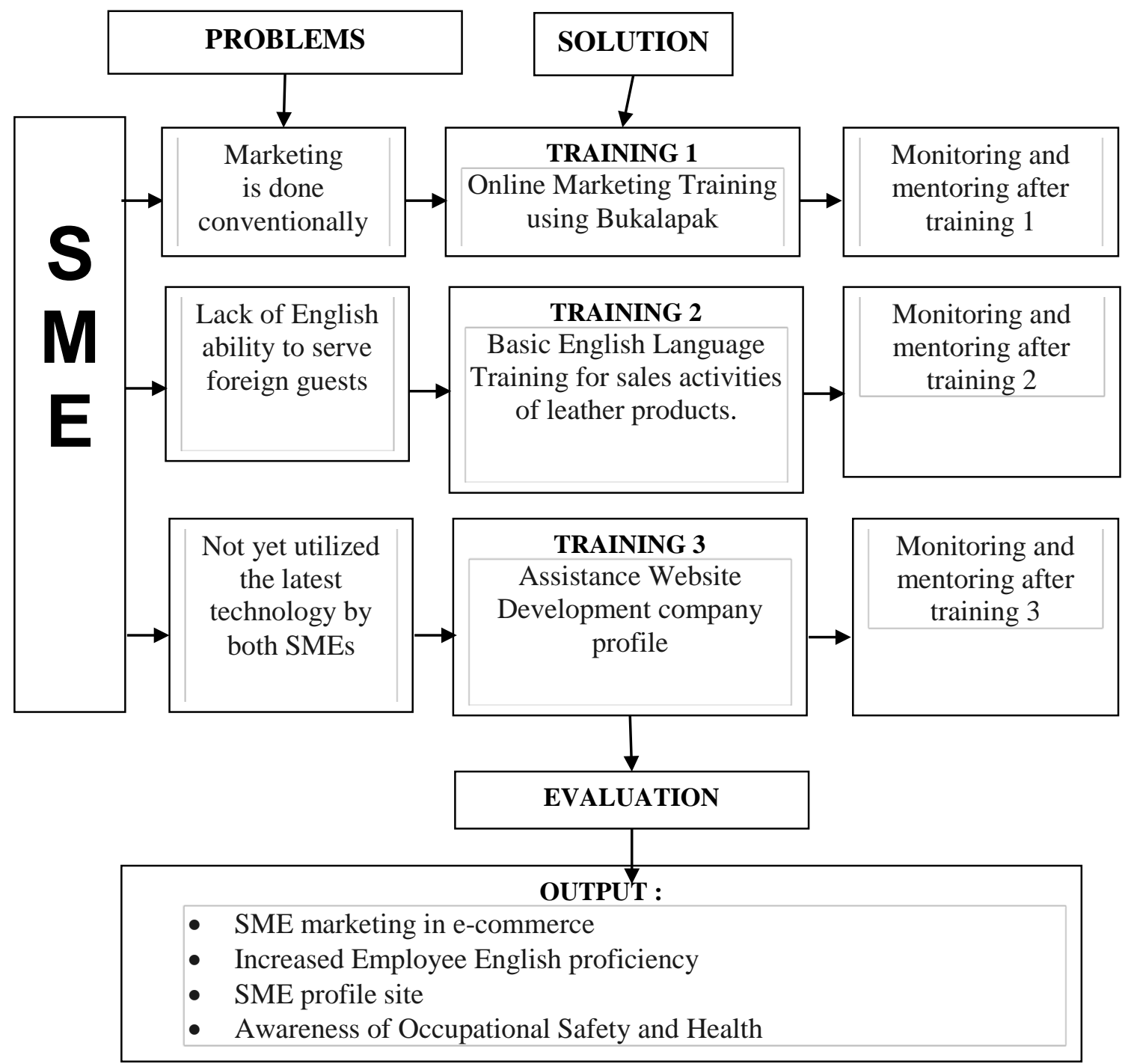

Figure 2. Method of Implementation.

\section{Results}

Activities and Training that have been implemented are as follows:

1 Survey of readiness CV. CMP and UD. DJA is immortal for the training to be undertaken.

2 Coordination meeting with both SMEs on human resources to be trained and training specifications.

3 Marketing Training Online

A Participants recognize e-commerce and its opportunities.

B Participants know how to sell products to the national e-commerce Bukalapak.

4 Advanced Online Marketing Training to support previous online marketing training. 
C Participants can receive orders at Bukalapak

D Participants can ship orders via existing courier

E Participants may receive payments from customers who purchase through Bukalapak

5 Practical English Training, participants know how to serve the buyers of leather products in English

6 Assistance Website Creation

A. Website created is a website to display company profile and merchandise.

B. Website created through Blogger, a site from google to help users create a website. Sample Website can be accessed through http://permatatanggul.blogspot.co.id/ dan http://citramulyaperkasa.blogspot.co.id/

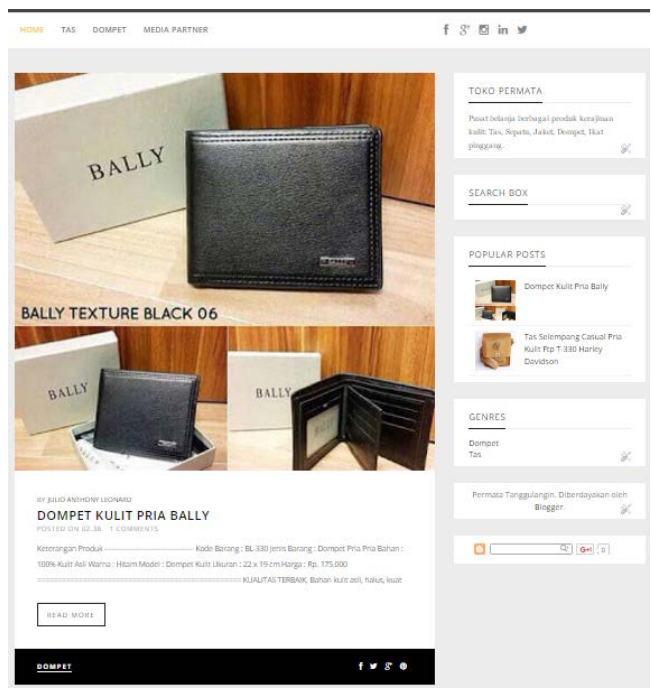

Figure 3. Example Website.

\section{Conclusions}

1. Based on the situation analysis on the condition of SMEs CV CMP and UD DJA in Sidoarjo district, East Java province, it is known that both SMEs have high quality products and deserve to be exported.

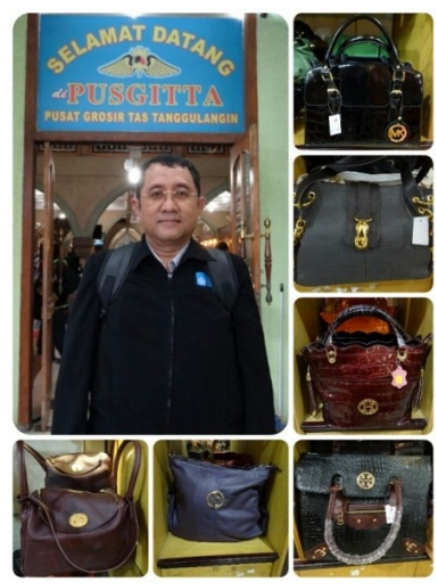

Figure 4. Leather Craft Products.

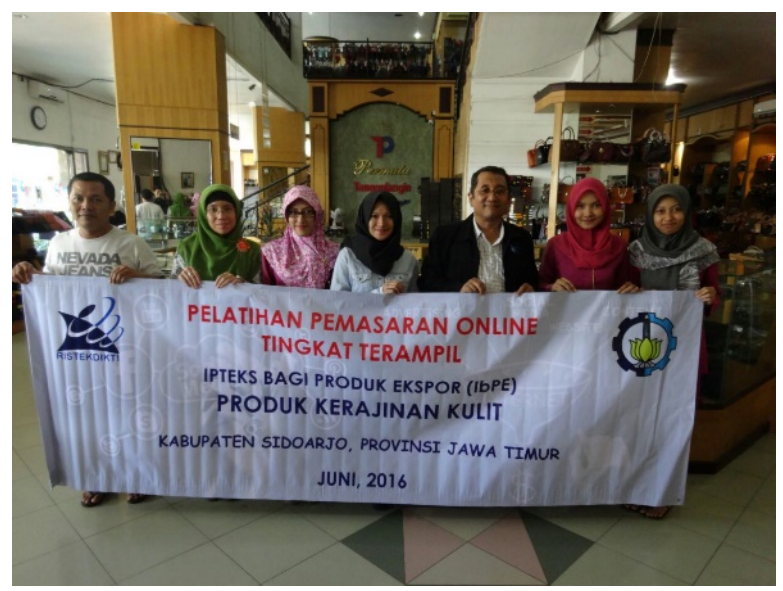

Figure 5. Online Marketing Training. 
2. This stage is still the initial stage of training and mentoring lasting less than 3 months. So the ecommerce sites used still use national sites such as Bukalapak to make participants accustomed to using e-commerce. After that will be used other e-commerce sites such as Tokopedia, Bliblibli, and when the participants are more advanced then it will be used Alibaba, and Ebay for overseas marketing.

3. Participants are very interested in learning something new like English, but for practical skills it still takes time so that participants can become more proficient.

4. Website created not yet have many visitors because it has not been long made. SMEs will continue to be monitored to add content and be consistent in running the program

5. Occupational Health and Safety have been fostered compare to previous condition.

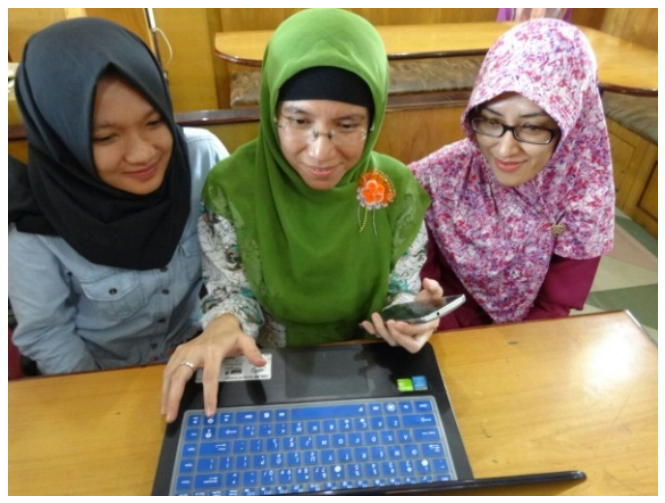

Figure 6. Website creation training.

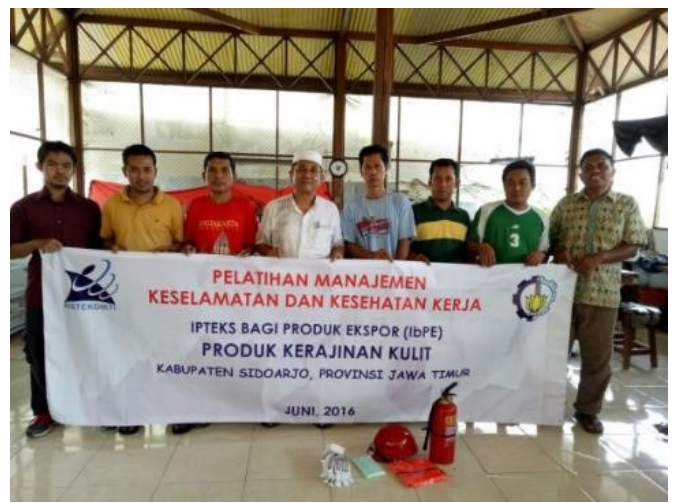

Figure 7. Occupational Health and Safety Training.

\section{References}

1. Kong F, Liu H. Applying fuzzy analytic hierarchy process to evaluate success factors of ecommerce. Int J Inf Syst Sci. 2005;

2. Nurmianto. Ergonomi Konsep Dasar dan Aplikasinya. Pengukuran Dan Perenc Sietem Kerja(Antropometri Dan Desain Produk). 2004;

3. Lehto MR, Landry SJ, Buck J. Introduction to human factors and ergonomics for engineers. Boca Raton, Florida: CRC Press, Taylor \& Francis Group; 2008. 770 p.

4. Torp S, Moen BE. The effects of occupational health and safety management on work environment and health: A prospective study. Appl Ergon. 2006 Nov 1;37(6):775-83.

5. Yeow PHP, Nath Sen R. Quality, productivity, occupational health and safety and cost effectiveness of ergonomic improvements in the test workstations of an electronic factory. Int $\mathrm{J}$ Ind Ergon. 2003 Sep 1;32(3):147-63.

6. Dul J, Neumann WP. Ergonomics contributions to company strategies. Appl Ergon. 2009 Jul 1;40(4):745-52.

7. Lin RJ, Ramakrishnan S, Chang H, Spraragen S, Zhu X. Designing a web-based behavior motivation tool for healthcare compliance. Hum Factors Ergon Manuf Serv Ind. 2013 Jan 1;23(1):58-67.

\section{Acknowledgments}

Authors wishing to acknowledge that this IBPE program research was financially supported from Directorate General of Higher Education, Ministry of Technology Research and Higher Education, Republic of Indonesia 